\title{
Literatura e sociedade: como a idéia de nação é re-dimensionada no poema de Drummond?
}

\author{
Maria do Socorro Aguiar Pontes ${ }^{1}$
}

\section{Resumo}

Este artigo pretende discutir como o conceito de nação é re-dimensionado no poema Hino nacional de Carlos Drummond de Andrade, dentro do contexto do Modernismo. A partir disso, lança-se hipóteses com vistas a possíveis desdobramentos e conseqüências para o estudo da literatura brasileira.

Palavras-chave: Carlos Drummond de Andrade, Hino nacional, nação e Modernismo.

\section{Résumée}

Cet article a pour but discuter comment le concept de nation est re-dimensioné dans le poème Hino Nacional de Carlos Drummond de Andrade, dans le contexte du Modernisme. À partir de cela, des hypothèses sont faites à propos de conséquences possibles pour l'étude de la littérature brésilienne.

Mots-clé: Carlos Drummond de Andrade, Hino nacional, nation et Modernisme.

Para fazer crítica, é necessário ter por base a própria obra, a fim de se compreender aquilo que nela está subsumido; em outras palavras, é das intuições, sugeridas pelo texto literário - para esse ponto converge a opinião de muitos críticos que se pode partir para outras explicações - de ordem sociológica, por exemplo - sob pena de incorrer em leituras precipitadas, ou seja, leituras de fora para dentro, que podem até ser válidas (como interpretações da história de um dado povo), contanto que não se pretendam exegese do corpus em análise. A grande obra de arte não é panfletária, pois esta já se esgota no próprio nascedouro, mas ela carrega em si, como constituição mais íntima e profunda, aspectos refletidos da sociedade em que se insere, como explica Adorno no seguinte trecho:

Esse pensamento, porém, a interpretação social da lírica, como aliás de todas as obras de arte, não pode portanto ter em mira, sem mediação, a assim chamada posição social ou a inserção social dos interesses das obras ou até de seus autores. Tem de estabelecer, em vez disso, como o todo de

\footnotetext{
${ }^{1}$ Licenciada em letras e mestranda em literatura no Departamento em Teoria Literária e Literaturas pela Universidade de Brasília.
} 
uma sociedade, tomada como unidade em si mesma contraditória, aparece na obra de arte; mostrar em que a obra de arte lhe obedece e em que a ultrapassa. O procedimento tem de ser, conforme a linguagem da filosofia, imanente. Conceitos sociais não devem ser trazidos de fora às composições líricas, mas sim devem surgir da rigorosa intuição delas mesmas. ${ }^{2}$

Dessa maneira, se não se pode reduzir toda a literatura, enquanto arte da palavra, à história, não se pode prescindir desta para compreender-lhe as entranhas e os significados mais profundos. Ela nasce com a história, na história e através da história. Exatamente por isso, para uma melhor compreensão e interpretação do poema, Hino Nacional de Carlos Drummond de Andrade, parto de alguns autores que estudaram a literatura tendo por perspectiva uma visão histórica, sem escapar, entretanto, à análise do artefato literário.

As análises puramente estéticas ou historicistas, aliás, não deram conta da complexidade da literatura: sem olhar para o passado, não é possível re-pensar o presente, nem re-construir o futuro; tampouco, sem pensar na obra de arte ela mesma, é possível fazer hermenêutica. Quanto à polarização entre esteticistas e historicistas, Benedetto Croce propõe um tipo de análise em que uma não pode estar desvinculada da outra:

\begin{abstract}
A poesia é um fato histórico, mas um fato histórico que tem a sua própria qualidade, diferente da dos demais fatos históricos, e, se como todos os demais ela parte da realidade existente, indo além dessa realidade determinada, o seu ir além e criar consiste na conjugação intuitiva e na fusão do particular com o universal, do indivíduo com o cosmos, e (como Goethe disse uma vez da arte geral) seu ponto de partida é o "característico", mas seu resultado é a "beleza". Por isso, a sua interpretação histórica é, no próprio ato, interpretação estética, que não é negação da historicidade. Assim, dá no mesmo chamar essa interpretação de "histórica", entendendo-se "interpretação histórica da poesia", ou "estética”, entendendo-se "da poesia historicamente existente". 3
\end{abstract}

É ainda importante observar que a obra de arte carrega em si esta resistência que é social e ao mesmo tempo antitética, conforme Adorno (1988, p. 19), com relação à sociedade porque dela constitui uma crítica. O poema está inserido dentro da sociedade

\footnotetext{
${ }^{2}$ ADORNO, Theodor. "Palestra sobre lírica e sociedade". Nota de literatura I. p. 67

${ }^{3}$ CROCE, Benedetto. A poesia: introdução à crítica e história da poesia e da literatura. p. 98.
} 
como fruto ao mesmo tempo em que é uma antítese por resistir à onda de reificação em que o mundo capitalista pretende submergir a obra de arte.

Este artigo tem por finalidade discutir como o conceito de "nação" (vale ressaltar que a tentativa de compreensão da constituição da nacionalidade brasileira já havia sido alvo de discussão desde a época do Romantismo) é re-dimensionado no poema de Drummond. Proceder-se-á a uma análise, seguida de uma interpretação, sem dispensar alusões a outras fontes literárias nacionais à medida que se tornar interessante e necessário. Optei por comentar estrofe por estrofe para facilitar a leitura e a compreensão da interpretação aqui sugerida, mas, no final do artigo, logo após as referências bibliográficas, anexei o poema inteiro.

Hino nacional, a começar pelo próprio título, alude claramente ao hino nacional brasileiro, à diferença que enquanto este fica apenas no discurso acrítico e meramente laudatório (as crianças são forçadas a cantar sem serem convidadas pelo professor a fazerem uma reflexão acerca da letra da música), aquele esforça-se para, através dos questionamentos lançados, trazer alguma luz à idéia do Brasil. Aliás, como explica o professor Antonio Candido, a literatura brasileira, bem como as latino-americanas, diferentemente das européias, é eivada desse "empenho", desse comprometimento com a construção de uma nação:

\begin{abstract}
Quero me referir à definição da nossa literatura como eminentemente interessada. Não quero dizer que seja "social", nem que deseje tomar partido ideologicamente. Mas apenas que é toda voltada, no intuito dos escritores ou na opinião dos críticos, para a construção duma cultura válida no país. Quem escreve, contribui e se inscreve num processo histórico de elaboração nacional... A literatura do Brasil, como a dos outros países latino-americanos, é marcada por este compromisso com a vida nacional no seu conjunto, circunstância que inexiste nas literaturas dos países de velha cultura. Nelas, os vínculos neste sentido são os que prendem necessariamente as produções do espírito ao conjunto das produções culturais; mas não a consciência, ou a intenção, de estar fazendo um pouco da nação ao fazer literatura. ${ }^{4}$
\end{abstract}

É importante mencionar que o poema de Drummond insere-se no contexto do Modernismo, cuja pedra de toque, segundo as palavras de Afrânio Coutinho, é o "problema da valorização da realidade brasileira" (1959, p. 70) e que se caracterizou

${ }^{4}$ CANDIDO, Antonio. Formação da literatura brasileira. p.18. 
como uma tentativa de resgatar as nossas raízes para trazer à literatura a consciência do homo brasiliensis. Já com os Românticos - José de Alencar, por exemplo - houve tal iniciativa, mas, a partir deste momento da história do Brasil, tendo como marco inaugural a Semana da Arte Moderna de 1922, houve maturidade para se chegar a ter uma visão mais ampla acerca do que seria esta identidade e em que e como a literatura estaria ligada a ela. O próprio Macunaíma é uma rapsódia que busca criar a história do brasileiro (sua cosmogonia), através do uso da mitologia, na busca de uma compreensão e construção da identidade nacional. $\mathrm{O}$ trecho a seguir, segundo o narrador criado por Mário de Andrade, seria uma explicação mitológica das origens deste povo:

Quando o herói saiu do banho estava branco louro e de olhos azuizinhos, água lavara o pretume dele. E ninguém não seria capaz mais de indicar nele um filho da tribo retinta dos Tapanhumas.

Nem bem Jiguê percebeu o milagre, se atirou na marca do pezão do Sumé. Porém a água já estava muito suja da negrura do herói e por mais que Jiguê esfregasse feito maluco atirando água pra todos os lados só conseguiu ficar da cor do bronze novo...

Maanape então é que foi se lavar, mas Jiguê esborrifara toda a água encantada pra fora da cova. Tinha só um bocado lá no fundo e Maanape conseguiu molhar só a palma dos pés e das mãos. Por isso ficou negro bem filho da tribo dos Tapanhumas. ${ }^{5}$

A seguir, passo à análise e à interpretação do poema propriamente dito.

Hino nacional

Precisamos descobrir o Brasil Escondido atrás das florestas, com a água dos rios no meio, o Brasil está dormindo, coitado. Precisamos colonizar o Brasil.

Do ponto de vista formal, a primeira estrofe foi muito bem arquitetada pelo poeta. Encontra-se, apenas aí, várias ferramentas próprias do artefato poético, a fim de fazer emergir do texto o máximo de significações possíveis. É possível perceber a aliteração do "r" e a do "s" - que, como está entre duas vogais em todas as suas aparições, tem o som de /z/ - ambas para trazer a atenção à palavra "Brasil". Ainda é possível observar a assonância das vogais "i" e "a", também, mais uma vez, para

${ }^{5}$ ANDRADE, Mário de. Macunaíma: um herói sem caráter. p. 30 
enfatizar a palavra "Brasil". Portanto, o uso de tais recursos está diretamente relacionado com a própria intenção do poeta, qual seja a de fazer recair a atenção do leitor sobre a palavra-chave do poema. Tal propósito é tanto mais perceptível quando nota-se que a palavra "Brasil" é repetida três vezes, apenas na primeira estrofe, e será retomada ainda tantas outras (aparece dez vezes ao longo do poema de sete estrofes).

O primeiro verso da primeira estrofe já começa com uma exclamação (Precisamos descobrir o Brasil!). O poeta conclama pessoas (afinal quem são esses "nós"?) no sentido de descobrir o Brasil. A preocupação com a coletividade é tão maior que o poeta não se vale de um "eu" para expressar as questões sociais, mas sim de um "nós". Não só o poeta é responsável, nem só um leitor que se identificaria com um possível eu-lírico, mas todos "nós". Vale ressaltar também que o pronome "eu" não se encontra em nenhuma parte do poema, nem em desinência verbal que denunciaria a sua presença. Ainda que seja uma primeira pessoa, é a primeira do plural e, no uso dela, está a consciência da necessidade de participação de todos para essa nova descoberta do país. Existe, porém, aí, um aparente contra-senso, lançado propositadamente pelo poeta, uma vez que, se o Brasil - até mesmo pelo fato de possuir um nome - já foi descoberto, como pode ser descoberto novamente? O poeta não fala em re-descobrir, o que seria imediatamente compreensível (e também reducionista), dado o contexto histórico, mas simplesmente "descobrir", como se estivesse coberto.

Ora, o território, que hoje corresponde ao Brasil, já existia antes da chegada dos colonizadores. Foi necessário que os europeus, detentores do processo civilizatório, que, em sua própria essência, também é um processo de barbárie, chegassem aqui para dar um nome (como para dar a lume) o nascimento desta nação. Pode ler-se este verso como uma necessidade de descobrir o Brasil no sentido de ultrapassar todo arcabouço ideológico construído até então, i.e., uma necessidade de re-dimensionar a idéia desta nação. Para além desta visão do paraíso (escondido atrás das florestas/com as águas dos rios no meio), a que se resumiu a idéia de Brasil desde o cânone colonial (como em $\grave{A}$ ilha da maré, poema gigantesco no qual se louva a natureza do país), passando pela tomada de consciência pelos Românticos e chegando até o Modernismo, é possível transpor - o que parece que as duas estrofes seguintes vêm confirmar - a imagem do Brasil "gigante pela própria natureza" 6 .

\footnotetext{
${ }^{6}$ ESTRADA, Joaquim Osório Duque. Hino nacional.
} 
Lê-se "descobrir" - que, segundo o Houaiss, é "dar a conhecer alguma coisa a alguém" - na mesma dimensão de "colonizar"; os dois verbos, portanto, carregam a marca do explorador. Afinal, foram os portugueses, ávidos de riquezas, que descobriram e colonizaram o Brasil. Interessante notar que o poeta vale-se justamente das ferramentas, das armas lingüísticas do opressor, para fazer ressaltar uma voz emancipatória, a despeito desse aparente colonialismo interiorizado. Em outras palavras, nós mesmos, segundo a proposta do poeta, na condição de ex-colonizados e exdescobertos, iremos agora colonizar e descobrir o nosso país.

Afinal, o movimento modernista, no qual o poema se inscreve, tem justamente esta lógica, esta idéia de re-descobrir o Brasil, criar uma nação, uma vez que, conforme as palavras de Paulo Arantes, "o nacionalismo não acorda uma nação entorpecida por uma alienação secular, ele simplesmente inventa a nação que antes não existia." (2006, p. 27).

Esta lírica não é, porém, a de um indivíduo apenas, mas de vários “nós”, várias vozes que precisam ser ouvidas como num diálogo, pensando criticamente o país. O poeta traz à tona não apenas um discurso, mas vários possíveis que se estruturam e interligam-se pela lógica do "nós". Através da mesma fruição, os leitores sentem-se despertados a enfrentarem as questões sociais do Brasil, inclusive a própria literatura; o poema é um chamado para a construção e a re-construção da idéia de nação.

Em outros termos, o leitor é convidado a identificar-se com o "nós" do poema. Ele aí se inclui e, ao mesmo tempo, sabe que não é o único; existem outros que também fazem parte desse "nós"; o eu-lírico, o leitor e a co-participação, em potencial, de outros leitores. Benedetto Croce chama justamente de revocação da poesia esta identificação do leitor com o "eu" da poesia:

Ora se a expressão poética renasce de tempos em tempos no "eu" que se modifica, ela igualmente renasce nos outros homens que, devido à humanidade comum, identificam-se com esse "eu" e são seus contemporâneos e seus pósteros através dos séculos. Isto é o eterno renascer; é a revocação da poesia ${ }^{7}$.

\footnotetext{
${ }^{7}$ CROCE, Benedetto. A poesia: introdução à crítica e história da poesia e da literatura. p. 79.
} 
Vale ressaltar que o poema lança questionamentos e dúvidas ("o que faremos importando francesas" / "Acaso existirão os brasileiros?”) que fazem parte da própria história do Brasil, além do fato de, em momento algum, recorrer a uma idealização do passado para a compreensão da idéia de nação (existe, isto sim, uma postura crítica e irônica a esse tipo de visão). A questão social não está simplesmente nas entrelinhas ela é pronunciada claramente, ao longo do poema, através, dentre outros recursos, do sintomático "nós" - apesar de, como asseverou o professor Antonio Candido, a obra de Drummond ser "expressão política sem qualquer aspecto de programa, como se fosse manifestação da mais profunda necessidade pessoal.” (2007, p. 102).

Muito embora não se possa reduzir a poesia, nas palavras de Benedetto Croce, à "representante de povos e partidos ou polêmica, grito de revolta ou de guerra, indústria e astúcia, arma de combate e até exposição de idéias, sistemas e crenças" (1967, p. 164), o poeta acaba, pelo próprio artefato poético de que se vale, trazendo tudo isso à tona, não de modo unívoco e unilateral, mas nos recônditos, nas entrelinhas da tessitura da obra poética.

\footnotetext{
O que faremos importando francesas

Muito louras, de pele macia, alemãs gordas, russas nostálgicas para garçonettes dos restaurantes noturnos. E virão sírias fidelíssimas.

Não convém desprezar as japonesas...
}

Interessante perceber que o poeta fala dessas nacionalidades (francesa, alemã, síria, japonesa, além de outras, sugeridas pelo uso das reticências) correlacionando-as apenas a mulheres. A figura da mulher estrangeira aparece aí duplamente reificada: primeiramente sob o signo do trabalho alienado ${ }^{8}$ ("garçonette de restaurantes noturnos") e também como objeto de desejo (mulheres estrangeiras que vêm ao Brasil para trabalharem como prostitutas, afinal não se trata de qualquer restaurante, mas sim de restaurantes noturnos). É possível importar coisas, objetos, não mulheres ou, como na terceira estrofe, "comprar professores". Há também uma crítica ao fato de valorizarmos

\footnotetext{
${ }^{8}$ É interessante perceber que existem duas camadas de significado para tal trabalho e que ambas estão ligadas; a primeira delas é o trabalho como garçonete e a segunda como prostituta. Ou seja, sob as aparências do sintagma, esconde-se o principal motivo por que se "importava" tais estrangeiras.
} 
tudo aquilo que vem de fora, como bem demonstra o tom irônico do último verso "não convém desprezar as Japonesas...”.

Precisamos educar o Brasil.

Compraremos professores e livros,

assimilaremos finas culturas,

abriremos dancings e subvencionaremos as elites.

A voz que diz "Precisamos educar o Brasil." soa absolutamente superficial e falsa, como o discurso de um demagogo. Parece a representação da perspectiva de uma elite, que usa termos e expressões desgastadas, mas nada faz em prol da população, como se as palavras substituíssem a necessidade da ação. Aliás, como a própria tradição política do Brasil em que se fala muito para não dizer nada; quanto mais floreios o discurso possui, mais vazio ele é. Através dessa maneira de apresentar a fala de um determinado tipo da sociedade brasileira, ao lançá-la como uma das vozes do texto, o poeta isenta-se de cair em julgamentos apriorísticos, o que seria conseqüentemente uma redução da dimensão dos possíveis significados suscitados pela interpretação da obra. Dessa forma, sugere o debate sem, entretanto, direcioná-lo ou torná-lo totalizador - o que, por si só, já seria reducionista e cairia no erro da arte panfletária, caminho este que o escritor definitivamente rejeita.

Que finas culturas serão assimiladas? Se existem finas culturas, é porque existem, em contrapartida, culturas consideradas grosseiras e, neste caso, que culturas grosseiras seriam estas? As culturas dos índios e dos negros que ajudaram na constituição daquilo que seria o homo brasiliensis? Culturas estas que foram esmagadas pela matriz lusa? Sem sombra de dúvida, o poeta vale-se aqui, uma vez mais, dum tom irônico, para criticar a aceitação e o deslumbramento acrítico de tudo aquilo que é estrangeiro.

A propósito, as palavras "dancings" e "garçonettes" aparecem em itálico no poema de Drummond, primeiramente porque são estrangeirismos, mas também - se é consenso que, em matéria de poesia, não há uma vírgula que não traga um significado, um plus na arquitetura da obra poética - tem muito a ver, dado o contexto do poema e do tema a respeito do qual trata, com a relação que o brasileiro estabelece com a cultura 
que vem de outras paisagens. A aparição dessas duas palavras, uma de origem francesa, outra de origem inglesa (inclusive grafadas como na língua-mãe), demonstra que, malgrado os esforços da inteligência brasileira, ainda era possível perceber, na época em que o poema foi escrito (até mesmo hodiernamente) uma subserviência ao que vem de fora.

Dessa maneira, sinaliza que, para se construir uma idéia de nação, é preciso ir além. Se, por um lado, não se pode curvar sobre si mesmo ("nossas revoluções são bem maiores/do que quaisquer outras; nossos erros também), sobre a própria cultura, e achar que é o suficiente; por outro, a abertura para fora não pode ser um gesto de subserviência e genuflexão ante ao fetichismo da cultura européia, mas superação desta mesma condição, através do resgate e da valorização, não sem uma visão crítica, das nossas origens e das nossas idiossincrasias.

Cada brasileiro terá sua casa

Com fogão e aquecedor elétricos, piscina, salão para conferências científicas.

e cuidaremos do Estado Técnico.

O discurso, trabalhado no poema de forma irônica, revela-se utópico porque impossível. Se a maior parte dos brasileiros não tem sequer uma casa para morar, quanto mais "fogão e aquecedor elétricos, piscina, salão para conferências científicas." Inscreve-se ele também dentro da lógica do fetiche da mercadoria, já que tais objetos não fazem parte das necessidades básicas; aliás, são criações a fim de alimentarem a lógica da sociedade de consumo.

Além disso, tal "salão para conferências científicas" (enjambement que é muito significativo, pois destaca o sintagma ao isolá-lo num único verso) é absolutamente postiço. Se a maior parte da população brasileira, à época em que o poema foi escrito, era analfabeta, um "salão para conferências científicas" só pode soar como algo totalmente irônico. Isso também faz parte daquilo que Sérgio Buarque de Holanda sinalizou a respeito da nossa cultura livresca e artificial, na qual o conhecimento é mero ornamento e não funciona como questionamento profundo dos pressupostos da sociedade: 
Ainda quando se punham a legiferar ou a cuidar de organização e coisas práticas, os nossos homens de idéias eram, em geral, puros homens de palavras e livros; não saíam de si mesmos, de seus sonhos e imaginações. Tudo assim conspirava para a fabricação de uma realidade artificiosa e livresca, onde nossa vida verdadeira morria asfixiada...

O amor bizantino dos livros pareceu, muitas vezes, penhor de sabedoria e indício de superioridade mental, assim como o anel de grau ou a carta de bacharel. $^{9}$

Machado de Assis, n’ $O$ Alienista, também já havia tratado da questão do discurso cheio de enfeites e malabarismos gramaticais, mas absolutamente vazio, através da figura de um dos seus personagens que foi recolhido à Casa Verde, o nome que Simão Bacamarte havia dado ao hospital psiquiátrico, simplesmente pelo fato de ter proferido algumas palavras que chamavam por si só muito atenção, mas nada significavam em essência.

\author{
Precisamos louvar o Brasil. \\ Não é só um país sem igual. \\ Nossas revoluções são bem maiores \\ Do que quaisquer outras; nossos erros também. \\ e nossas virtudes? A terra das sublimes paixões... \\ Ou Amazonas inenarráveis... os incríveis João-Pessoas...
}

Esta obra de Drummond faz uma clara alusão, especialmente esta estrofe, às literaturas de viagem, nas quais se exaltava o Brasil pela sua natureza magnífica e grandiosa. Interessante como ele se re-apropria dessa visão a respeito do Brasil para dizer "Nossas revoluções são bem maiores" e não frutas ou legumes como se observa, por exemplo, no trecho abaixo, do poema À ilha da maré de Manuel Botelho. Destarte, cria-se uma lógica interna da literatura, uma "continuidade", a partir da retomada de outras obras que formam um "sistema literário", para usar os termos de Antonio Candido.

As laranjas da terra

Poucas azedas são, antes se encerra

Tal doce nestes pomos,

\footnotetext{
${ }^{9}$ HOLANDA, Sérgio Buarque de. Raízes do Brasil. p. 122.
} 
Que o tem clarificado nos seus gomos;

Mas as de Portugal entre alamedas

São primas dos limões, todas azedas.

O mamão por freqüente

Se cria vulgarmente,

E não preza o Mundo,

Porque é muito vulgar em ser fecundo.

Ora, sabe-se muito bem que nenhuma revolução no Brasil foi concebida pelos oprimidos e todas as denominadas revoluções vieram de cima pra baixo e, diferentemente das que ocorreram em outros países, foram arquitetadas intelectualmente, como assevera Sérgio Buarque de Holanda:

É curioso notar-se que os movimentos aparentemente reformadores, no Brasil, partiram quase sempre de cima para baixo: foram de inspiração intelectual, se assim se pode dizer, tanto quanto sentimental. Nossa independência, as conquistas liberais que fizemos durante o decurso de nossa evolução política, vieram quase de surpresa; a grande massa do povo recebeu-as com displicência ou hostilidade. Não emanavam de uma predisposição espiritual e emotiva particular, de uma concepção da vida bem definida e específica, que tivesse chegado à maturidade plena. Os campeões das novas idéias esqueceram-se, com freqüência, de que as formas de vida nem sempre são expressões do arbítrio pessoal, não se "fazem" ou "desfazem" por decreto. A célebre carta de Aristides Lobo sobre o 15 de novembro é documento flagrante do imprevisto que representou para nós, a despeito de toda a propaganda, de toda a popularidade entre os moços das academias, a realização da idéia republicana. "Por ora - dizia o célebre paredro do novo regime - por ora a cor do governo é puramente militar e deverá ser assim. O fato foi deles, deles só, porque a colaboração de elemento civil foi quase nula. O povo assistiu àquilo bestializado, atônito, surpreso, sem conhecer o que significava." 10

Portanto, só é possível compreender o trecho "nossas revoluções são maiores", de forma irônica, como eram mais doces nossas laranjas e mais fecundos nossos mamões. O discurso que coloca tudo como maior, melhor, esse discurso hiperbólico, na verdade, é o mesmo que procura esconder as mazelas do país. Hiperboliza-se, às raias do fantástico, certas características de um determinado objeto (no caso o Brasil) a fim de esconder as verdades que as classes dominantes querem, a todo custo, esconder. Interessante notar a observação que Antonio Candido fez a respeito deste assunto:

${ }^{10}$ HOLANDA, Sérgio Buarque de. Raízes do Brasil. p. 120. 
Ligando-se à tendência hiperbólica freqüente, nas descrições da terra, esse espírito de argúcia se ajustou com facilidade ao Barroco, gerando um veio de exaltada celebração do país, que durante quase três séculos serviu de compensação para o atraso e o primitivismo reinantes. Do fundo do século XVII até quase nossos dias, o brasileiro se habituou a mascarar a realidade por meio de imagens e da ênfase, que mostravam o seu país como paraíso terrestre e lugar predestinado a um futuro esplêndido ${ }^{11}$.

Mas a poesia, a grande poesia tem essa capacidade de deixar falar o que a visão hegemônica procura camuflar, uma vez que, conforme Adorno, "obras de arte... têm sua grandeza unicamente em deixarem falar aquilo que a ideologia esconde. Seu próprio êxito quer elas queiram ou não, passa além da falsa consciência." (2003, p. 68)

Precisamos adorar o Brasil!

Se bem que seja difícil caber tanto oceano e tanta solidão no pobre coração já cheio de compromissos... se bem que seja difícil compreender o que querem esses homens, por que motivo eles se ajuntaram e qual a razão de seus sofrimentos.

Interessante perceber, logo de saída, que os dois termos "precisamos" e "adorar" de, algum modo, se opõem, pois causam no leitor certo estranhamento. Por intermédio do estranhamento que a arte pode causar, é possível ampliar o grau de consciência e observação, seja do leitor, do espectador, ou do observador de um quadro, por exemplo.

Afinal quem adora, adora de forma espontânea, não precisa adorar. O objeto adorado é adorado porque provoca naquele que o adora tal inclinação. Esse estranhamento, que causa ao leitor, é interessante porque faz com que ele se incline a prestar atenção ao se desabituar com o mecanismo da língua (sintagmas feitos, frases repetidas) para ler o significado por trás e dentro dos significantes. Lê-se esse verso também de uma maneira irônica, pois adorar o Brasil pode significar ser tomado por um deslumbramento tal a ponto de não se ter mais um espírito crítico.

O "pobre coração já cheio de compromissos" revela um eu-lírico dividido entre a solução dos problemas da vida prática e os da nação. Um coração que precisa conter, a

${ }^{11}$ CANDIDO, Antonio. Iniciação à literatura brasileira. p. 23. 
um só tempo, "tanto oceano" e "tanta solidão" (um substantivo concreto, o outro abstrato, ambos de naturezas completamente diferentes, portanto) dar a ver quão complicada é a condição do homem brasileiro que precisa reunir tamanhas forças, muito além das suas capacidades, pelo que a metáfora sugere, para compreender e se posicionar criticamente face à realidade do país. É difícil "compreender o que querem esses homens" porque o próprio contexto da constituição histórica do Brasil é problemático, o que o poeta continuará na última estrofe.

\author{
Precisamos, precisamos esquecer o Brasil! \\ Tão majestoso, tão sem limites, tão despropositado, \\ ele quer repousar de nossos terríveis carinhos. \\ O Brasil não nos quer! Está farto de nós! \\ Nosso Brasil é no outro mundo. Este não é o Brasil. \\ Nenhum Brasil existe. E acaso existirão os brasileiros?
}

O poeta nos remete à idéia de que é necessário esquecer o Brasil neste sentido de "majestoso", "tão sem limites", "tão despropositado", isto é, esta abordagem do Brasil apenas como um país que, por ser tão gigante, torna-se o país do futuro (existe um problema neste sintagma, já que, se se diz que um determinado país é do futuro, este mesmo futuro estará sempre no futuro e nunca chegará). Interessante observar o fato de certo escritor alemão - que morou no Brasil por algum tempo - ter escrito, em 1941, um livro cujo título era justamente Brasil: um país do futuro. Nele Zweig faz um verdadeiro elogio à civilização brasileira e diz que o Brasil “... está fadado a ser um dos fatores mais importantes do desenvolvimento futuro de nosso mundo..." (2006, p.14). Com o passar do tempo, o sintagma acabou tomando traços irônicos. O lema da própria bandeira nacional, "Ordem e progresso", já parece indicar esse talento para o futuro do país, terra do nunca, terra das eternas promessas, como se houvesse uma profecia certa para o porvir.

O pensamento hegemônico, aliás, quer impor à sociedade que esta sempre está em constante progresso e que a história tem um começo, um meio e um fim; se somos subdesenvolvidos é porque ainda não alcançamos o progresso, mas que, trabalhando e acreditando no futuro da nação, um dia iremos alcançar (discurso demagógico). Os donos do poder procuram disfarçar a realidade tal qual é a fim de manter o domínio 
sobre a sociedade. Gilberto Dupas define progresso como uma "... idéia-força que se confunde com um discurso hegemônico encastelado no anseio universal de uma marcha para a utopia" (2006, p. 22).

É preciso, pois, mudar o foco, mudar a perspectiva, mudar o olhar, para descobrir o próprio país, pois "nosso Brasil é no outro mundo" e "nenhum Brasil existe", porquanto as velhas formas de compreensão da nação, até o Modernismo, embora haja muito a explorar, ainda não haviam chegado à altura das potencialidades que o país encerrava e encerra.

Se o poeta afirma que este não é o Brasil, certamente é porque existe a possibilidade de se construir uma interpretação diferente da história. Não este país professado pelos políticos demagogos - que prometem "casa com fogão e aquecedor elétricos, piscina/salão para conferências científicas", mas incapazes sequer de oferecer uma qualidade de vida mínima a este povo - ou um Brasil "tão majestoso, tão sem limites, tão despropositado", "a terra das sublimes paixões" ou ainda a dos "Amazonas inenarráveis...”. Drummond sugere pensar o Brasil a partir de uma perspectiva outra que os próprios leitores terão de descobrir - completamente diferente dessas construções ideológicas que haviam sido feitas até então.

E o questionamento final: acaso existirão os brasileiros? Afinal quem são os brasileiros? Os negros, os índios, os portugueses, os imigrantes? Acaso existirão os brasileiros no sentido também de um questionamento mais profundo a respeito desta mesma identidade? Sentir-se-ão tais brasileiros realmente brasileiros se não encontram sequer condições de vida mínimas para serem, de fato, congregados numa nação?

O Brasil nasce como uma colônia, sob o signo da exploração de Portugal na história das expansões ultramarinas. Não passamos por todos os processos por que passaram as nações européias até se tornarem capitalistas. Já pegamos o bonde da história andando e nos agarramos porque não nos restava outra opção. Quando os Portugueses vieram para a América, a intenção era explorar. Os povos indígenas, que aqui estavam, senão foram totalmente aniquilados pelos opressores, sofreram, em grande parte, para inverter um pouco os termos, um processo de antropofagia espiritual e cultural. Populações africanas vieram para cá, pura e simplesmente, para servir como trabalho escravo. Essas vozes, como uma consequiência lógica, não conseguiram lograr ainda - com um discurso a partir de suas próprias perspectivas - uma grande expressão 
na história e na literatura brasileiras, o que de, algum modo, entraria no questionamento do último verso.

O Brasil, como o próprio Drummond fala, precisa ser descoberto; é necessário penetrar na história deste país e perceber que podem existir diversas interpretações. Uma literatura que expressa o seu povo e na qual ele é capaz de se reconhecer é uma literatura forte, uma literatura destinada não apenas a meia dúzia de intelectuais capazes de compreender a obra de arte, mas cada vez mais aberta a um público leitor que possa trazer novas interpretações e, até mesmo, opiniões dissonantes para o enriquecimento da crítica. O professor Flávio Kothe fala justamente sobre a necessidade de dar vez a essas diversas vozes que constituem e caracterizam a nacionalidade brasileira:

Tendo o Brasil se formado - na perspectiva tanto de arrogantes senhores quanto de mal-amados servos - como "lata de lixo da história”, onde foram jogados "a escória da sociedade", "aqueles que não deviam ter nascido", "o restolho dos diversos continentes", essa reprimida e escamoteada experiência de rejeição dos antepassados está subjacente em todos... Nesse sentido, o problema de uma imigração como a alemã é o mesmo de todas as outras minorias étnicas, e não só as dos imigrantes, mas também dos negros, que vieram forçados; dos índios, que perderam o domínio da terra; $e$ até mesmo dos portugueses, que em geral não vieram como enviados da corte, e sim condenados, discriminados, pessoas sem boas chances de desenvolvimento na terra de origem. Contra a própria vontade, todos se viram obrigados a buscar no território brasileiro o espaço de sua esperança. O problema das minorias é o problema da maioria, o problema de quase todos... ${ }^{12}$

O poema é grande arte porque, por meio da sua própria estrutura técnica, condensa vários questionamentos, diversos aspectos críticos que, em forma de prosa, levaria inúmeras laudas para explicar e, ainda assim, não teria a dimensão da obra que aqui pretendeu-se estudar. Como colonizados que fomos, como braço da cultura européia, nos termos de Antonio Candido "galho secundário da portuguesa" (1975, p. 9), marca a nossa literatura, bem como toda a nossa cultura, tal condição de colonizados, antes por Portugal e depois, culturalmente, pela França. Só passamos a existir a partir da cultura deles, no momento em que os "europeus" descobriram que aqui estávamos, mas este "nós" também é o povo português, também são os grupos

${ }^{12}$ KOTHE, Flávio. Cânone colonial. p. 38. 
indígenas que aqui estavam, também são os imigrantes que chegaram depois. É necessário, pois, expandir a possibilidade da leitura - do mundo e da palavra - para que, cada vez mais, as pessoas possam ter mais participação no mundo da arte no qual, a priori, supõe-se estarem representadas.

Mesmo que Antonio Candido diga que é necessário amar a literatura brasileira porque "é ela que nos exprime" (1975, p. 10), ainda existe uma ampla gama de classes que não encontra nela não apenas a sua representação, mas também não possui sequer acesso à leitura dela. Portanto, infelizmente a literatura acaba sendo para poucos num país como o Brasil. É preciso pluralizá-la, trazer estes outros "nós", de que tanto fala Drummond, para desembaraçar os outros nós que entravam o crescimento do povo brasileiro e o acesso a uma educação de qualidade. Se a literatura não pôde e não pode salvar a humanidade, sequer o povo brasileiro, ela pode, pelo menos, lançar questionamentos profundos a essa mesma sociedade para que se aventem novas possibilidades de interpretação da história e um futuro - deste povo e de sua arte diferente.

Faz-se necessário, além disso, abrir a nossa literatura a um debate com as outras literaturas latino-americanas cujos povos também sofreram o processo de colonização, uma vez que temos muito em comum historicamente, intelectualmente e artisticamente. É preciso superar a condição de ex-colonizados revisando e re-visitando o próprio cânone a fim de ampliar a nossa literatura para outros povos. A hipótese, aqui lançada, é que não apenas as literaturas produzidas pelas elites possam entrar para os debates, mas também as literaturas orais, as literaturas inclusive de imigrantes (que, em sua maior parte, simplesmente são ignoradas) e tantas outras para as quais a Academia ainda está de portas fechadas.

\section{Referências bibliográficas}

ADORNO, Theodor W. "Palestra sobre lírica e sociedade". Notas de literatura 1. São Paulo: Duas cidades/Ed. 34, 2003.

Teoria estética. Trad. de Artur Morão. São Paulo, Martins Fontes, 1988.

ANDRADE, Carlos Drummond de. "Hino nacional" in: Brejo das almas. Rio de Janeiro: Record, 2001. 
ANDRADE, Mário de. Macunaíma: o herói sem nenhum caráter. Belo Horizonte: Villa Rica Editoras, 1993.

ARANTES, Paulo. "Nação e reflexão" in: Benjamin Abdalla jr. e Salete de Almeida Cara. (org). Moderno de nascença, figurações críticas do Brasil. São Paulo: Boitempo, 2006, p. 27-45.

BOTELHO, Manuel. À ilha da maré. Publicação eletrônica, acessada em http://www.cce.ufsc.br/ nupill/literatura/ilhamare.html em 01 fevereiro 2010.

CANDIDO, Antonio. Formação da literatura brasileira: momentos decisivos. Vol I. 2ed. São Paulo: Martins, 1975.

Iniciação à literatura brasileira. Rio de Janeiro: Ouro sobre azul, 2007.

COUTINHO, Afrânio. A literatura no Brasil. Vol III. Tomo I. Rio de Janeiro: São José, 1959.

CROCE, Benedetto. A poesia: introdução à crítica e história da poesia e da literatura. Trad. de Flávio Loureiro Chaves. Faculdade de Filosofia da Universidade Federal do R. G. do Sul, Porto alegre, 1967.

DUPAS, Gilberto. O mito do progresso. São Paulo: Editora UNESP, 2006.

ESTRADA, Joaquim Osório Duque. Hino nacional. Publicação eletrônica, acessada em www.planalto.gov.br/ccivil_03/Constituicao/hino.htm em 05 fevereiro 2010.

HOLANDA, Sérgio Buarque de. Raizes do Brasil. 25 ed. Rio de Janeiro, Jose Olympio, 1993.

HOUAISS, Antônio \& VILlAR, Mauro de Salles. Dicionário Houaiss da língua portuguesa. Rio de Janeiro: Objetiva, 2001.

KOTHE, Flávio R. O cânone colonial. Brasília: Editora Universidade de Brasília, 1997.

ZWEIG, Stephan. Brasil: um país do futuro. Trad. de Cristina Michahelles. Porto Alegre: L\&PM, 2006.

\section{Hino nacional}

Precisamos descobrir o Brasil!

Escondido atrás das florestas, com a água dos rios no meio, o Brasil está dormindo, coitado.

Precisamos colonizar o Brasil. 
O que faremos importando francesas

Muito louras, de pele macia, alemãs gordas, russas nostálgicas para garçonettes dos restaurantes noturnos. E virão sírias fidelíssimas.

Não convém desprezar as Japonesas...

Precisamos educar o Brasil.

Compraremos professores e livros, assimilaremos finas culturas, abriremos dancings e subvencionaremos as elites.

Cada brasileiro terá sua casa com fogão e aquecedor elétricos, piscina, salão para conferências científicas.

E cuidaremos do Estado Técnico.

Precisamos louvar o Brasil.

Não é só um país sem igual.

Nossas revoluções são bem maiores do que quaisquer outras; nossos erros também. E nossas virtudes? A terra das sublimes paixões... os Amazonas inenarráveis... os incríveis João-Pessoas...

Precisamos adorar o Brasil!

Se bem que seja difícil caber tanto oceano e tanta solidão no pobre coração já cheio de compromissos...

se bem que seja difícil compreender o que querem esses homens, por que motivo eles se ajuntaram e qual a razão de seus sofrimentos.

Precisamos, precisamos esquecer o Brasil!

Tão majestoso, tão sem limites, tão despropositado, ele quer repousar de nossos terríveis carinhos.

O Brasil não nos quer! Está farto de nós!

Nosso Brasil é no outro mundo. Este não é o Brasil.

Nenhum Brasil existe. E acaso existirão os brasileiros?

(Carlos Drummond de Andrade) 